\title{
The Psychological Antecedents of Consumer Trust in Consumer-to-Consumer (C2C) E-Commerce: A Systematic Literature Review
}

\author{
Wina Salsabila $^{1^{*}}$ Zamralita Zamralita $^{1}$ Kiky D. H. Saraswati ${ }^{1}$ \\ ${ }^{1}$ Faculty of Psychology, Universitas Tarumanagara, Jakarta, Indonesia \\ "Corresponding author. Email: zamralita@fpsi.untar.ac.id
}

\begin{abstract}
The present study is a systematic literature review research of psychological antecedents of consumer trust in consumer to consumer $(\mathrm{C} 2 \mathrm{C})$ e-commerce. After conducting a literature search in 5 electronic databases (ScienceDirect, ResearchGate, GoogleScholar, Garuda and Psycnet), authors found 10 articles published between 2009 and 2020. The review revealed several psychological antecedents of consumer trust in C2C, there are perceived of website quality, natural propensity to trust, trust among members in C2C community, other's trust of buyer/seller, virtual community quality, perceived risk, perceived security protection, perceived privacy protection, cognitive trust, technology readiness, and fear of opportunism. In conclusion, psychological antecedents have the most important part in $\mathrm{C} 2 \mathrm{C}$. These results provide new insights toward theoretical understanding, and also provide useful guidance for $\mathrm{C} 2 \mathrm{C}$ web providers.
\end{abstract}

Keywords: Psychological antecedents, Consumer trust, Customer to customer $(C 2 C)$ e-commerce

\section{INTRODUCTION}

During the Covid-19 pandemic, there has been an increase in online sales in almost all countries [1]. There have been online purchasing behavior changes in Germany by $30 \%$, UK $46 \%$, and the US 52\% [2]. Indonesia also reported that there has been an increase in online sales since January 2020 [3].

One of the platforms used in online sales is the consumer to consumer (C2C) e-commerce platform. In Indonesia, C2C has been growing rapidly [4]. $\mathrm{C} 2 \mathrm{C}$ that includes the use of chat rooms, web forums, online auctions, and third-party consumer lists, is proven to be more popular than businessto-consumer (B2C) e-commerce [5]. However, there have been numerous cases of fraud and service failure that provide negative publicity and could weaken the company's reputation as a market leader [6]. Yanchun et al. [7] also mentioned with the amazing of $\mathrm{C} 2 \mathrm{C}$ growth in China, online trust has become the most important problem, as online fraud is one of the most important antecedents that can delay the development of $\mathrm{C} 2 \mathrm{C}$ in China [8]. Pono et al. [6] also mentioned that fraud cases directly affect public trust negatively, especially in the online selling process on $\mathrm{C} 2 \mathrm{C}$ sites

According to Beldad et al. [9], online transactions that are intangible can be affected by some problems that can lead to consumer's reluctance to engage in any form of online transactions, because computer-mediated transactions can create fear and anxiety. With credit card fraud, merchandise errors, and other security issues contributing to consumer reluctance to buy, the online purchase has a greater risk and uncertainty $[10,11,12]$.

Online trust is one of the most important factors because online environments such as $\mathrm{C} 2 \mathrm{C}$ present a feeling of uncertainty that can prevent consumers from making online purchases to become loyal customers [13]. Trust can be influenced by many factors [14], which has led researchers to conduct further exploration to get the additional focus of attention recently [15].

In this study, the authors want to find out more about the psychological antecedents that affect consumer trust in online purchases. Kotler and Armstrong [16] stated that consumer behavior is influenced by consumer psychology. According to Kotler and Armstrong [16], psychological antecedents are become the most attention factor on a marketer, because the marketer cannot control consumer psychology. Mou et al. [17] also mentioned that the factors that affect trust in online purchases are individual factors. Authors used PICo (Participant, Interest, and Context) to find the research question. Participants in this study focused on online consumers who have made transactions on $\mathrm{C} 2 \mathrm{C}$. The Interest of this study is about online consumer trust. And the context in this study is to understand the psychological antecedents that influence consumer trust in $\mathrm{C} 2 \mathrm{C}$. Thus, the research question of this study is what psychological antecedents that affect consumer trust in $\mathrm{C} 2 \mathrm{C}$ e-commerce? 


\section{LITERATURE REVIEW}

Punyatoya [18] defines consumer trust as a psychological state of online consumers that consists of the intention to accept vulnerability based on positive expectations of the online seller's intention or behavior. According to Bart et al. [19], online trust includes consumers' perceptions of how the website will meet expectations, how trustworthy the website's information is, and how trustworthy the site commands.

Punyatoya [18] proposes that consumer trust has two dimensions, cognitive and affective trust. According to Lewis and Weigert [20], trust develops from a rational thought (cognitive-based), linked with one's feelings, instincts, and intuitions (affective-based). Trust in the cognitive dimension is when individuals choose whom they will trust, in what way, and under what circumstances, and base these decisions on what they trust to be good reasons. The cognitive dimension in a trust is defined as the trust held by consumers that online sellers have the competence and can be relied on to fulfil their promises [18]

While the cognitive dimension refers to how a person develops "good reasons" that others can be trusted [18], the affective dimension refers to the "emotional bond" of trust that exists between parties [21]. In the field of sociology, Lewis and Weigert [20] explain that trust is built on an emotional basis that complements its cognitive base, this is what is called the affective component of trust. Morrow et al. [21] defined affective trust as instinct, intuition, or a person's feeling about a person, group, or organization that can be trusted. Punyatoya [18] defines affective trust as an emotional bond between consumers and companies, in which consumers trust online sellers based on instinct, intuition, or feeling generated by the level of care and attention shown by online sellers.

The literature study conducted by Chen [22] comprehensively leads to five relatively exclusive sources of trust, namely trust based on customer characteristics, website characteristics, calculus, institutions, and knowledge. According to studies in psychology and sociology, individual characteristics are considered as the main source that can influence the formation of an individual's trust in others [22]. A study shows that the quality of the website affects consumers' trust, intention, and positive attitudes towards the website [23]. The next factor that can influence consumer trust is calculus-based trust. A study shows that calculus-based trust is the main source from which initial trust can be developed [22]. For example, reputation usually serves as an important thing for large companies, where if the trust collapses, the company's reputation can be down throughout the consumer network [22]. The next factor is institution-based trust. Institutionalbased trust is related to situational normality and structural assurance [22]. Situational normality defines as the trust that may occur because the situation is normal or ordinary, or that everything appears to be in the right order [20]. Shapiro [24] defines structural assurance as structural protections such as regulations, guarantees, and legal assistance. Regulations such as company policies regarding privacy and security allow people to feel sure about their expectations of the future behavior of others [22]. In a consumer market environment, the familiarity between buyers and sellers through positive repeated interactions can increase the buyer's trust in the seller. In e-commerce, increased consumer knowledge and familiarity about the website can enhance these consumer predictions about future seller actions [25]

In an e-commerce environment, consumer trust is the most important part of the success factor [13, 26, 27, 28]. Several studies show that online trust influences online purchasing decisions [29, 30, 31, 32], intention to buy [33], satisfaction [34], and customer loyalty [35, 36, 37]. Trust is also the main key to building relationships with consumers [38].

\section{METHOD}

This study uses a systematic literature review method. Authors only use articles that discuss psychological antecedents that affect consumer trust in C2C. This study only used articles with abstract, full text, and included in Q1, Q2, Q3, and Q4 (international journals), and S1 and S2 (Indonesian journals). The databases used in this study are PsycNet, GoogleScholar, ScienceDirect, ResearchGate, and Garuda. The keywords used for screening articles are "trust", "psycholo* antecedents", and "e-commerce consumer to consumer (C2C)". The screening process was limited to scientific articles published in English or Indonesian. Thus, other language articles are in exclusion area. Articles that are not in Q1, Q2, Q3, and Q4, and S1 and $\mathrm{S} 2$ criteria are in the exclusion area. Articles published before 1995 are in the exclusion area because 1995 was the beginning of the internet commercialization for public use. The authors used a quality assessment from Nguyen et al. [39] that combines and adapts the quality assessment from Macpherson and Holt [40] and Wong et al. [41]. The screening process includes a review of theory, methodology and methods, analysis, relevance, and contribution (Table 1). The article must meet at least the first set of criteria and meet at least one of the quality criteria at level 3 to be analyzed further [41].

\section{RESULTS}

The result of this study has obtained 10 articles that meet the inclusion area. The result of this study has been summarized in Table 2 that contains sources, year of publication, journal title, number of samples, participants, methods, research locations, outcomes, and conclusions. This study found 1,118 articles obtained through the databases of Science Direct (422), Researchgate (120), Google Scholar (155), Garuda (257), and Psycnet (164). The authors then screened duplicate studies and got 1,057 articles. 1,047 articles were in the exclusion criteria so that only 10 articles are the subjects of this study.

The articles used in this study published between 2009 and 2020. A total of 10 articles (100\%) used in this study used quantitative methods. Based on the type of sample used, 6 articles $(60 \%)$ used internet users in general as a participant, 
and 4 articles (40\%) used university students as a participant. Most of the articles published in the field of information technology and e-commerce. 6 articles (60\%) were concerned with the information technology field, and 4 articles (40\%) were concerned with the e-commerce field. In terms of regional focus, most of the study used in this study are from China with a total of 6 articles $(60 \%)$, the USA with a total of 3 articles (30\%), and Indonesia with 1 article (10\%).

Table 1 Quality Assessment

\begin{tabular}{|c|c|c|c|c|}
\hline \multirow[b]{2}{*}{ Content } & \multicolumn{4}{|c|}{ Level } \\
\hline & $0=$ Absent & $1=$ Low & $2=$ Medium & $3=$ High \\
\hline Theory & $\begin{array}{l}\text { The article does not } \\
\text { provide } \\
\text { enough information to } \\
\text { assess this criterion }\end{array}$ & $\begin{array}{l}\text { Inadequate literature } \\
\text { review }\end{array}$ & $\begin{array}{l}\text { Acceptable literature } \\
\text { review }\end{array}$ & $\begin{array}{l}\text { Excellent literature } \\
\text { review }\end{array}$ \\
\hline $\begin{array}{l}\text { Methodology } \\
\text { and Methods }\end{array}$ & $\begin{array}{l}\text { The article does not } \\
\text { provide enough } \\
\text { information to assess } \\
\text { this criterion }\end{array}$ & $\begin{array}{l}\text { Not fully explained, } \\
\text { difficult to replicate }\end{array}$ & $\begin{array}{l}\text { Acceptable } \\
\text { explanation and } \\
\text { replicability }\end{array}$ & $\begin{array}{l}\text { Clear explanation and } \\
\text { excellent records for } \\
\text { audit trail }\end{array}$ \\
\hline Analysis & $\begin{array}{l}\text { The article does not } \\
\text { provide enough } \\
\text { information to assess } \\
\text { this criterion }\end{array}$ & $\begin{array}{l}\text { Insufficient data, } \\
\text { Weak connection in } \\
\text { research design }\end{array}$ & $\begin{array}{l}\text { Appropriate data } \\
\text { sample, } \\
\text { Adequate analysis but } \\
\text { weak explanation }\end{array}$ & $\begin{array}{l}\text { Adequate data } \\
\text { sample, } \\
\text { Data and results } \\
\text { strongly support } \\
\text { arguments, } \\
\text { Good explanation }\end{array}$ \\
\hline $\begin{array}{l}\text { Relevance } \\
\text { (findings, } \\
\text { theories, } \\
\text { methods) }\end{array}$ & $\begin{array}{l}\text { The article does not } \\
\text { provide enough } \\
\text { information to assess } \\
\text { this criterion }\end{array}$ & Little relevance & Broad relevance & $\begin{array}{l}\text { Integration of the } \\
\text { findings, theories and } \\
\text { methods }\end{array}$ \\
\hline Contribution & $\begin{array}{l}\text { The article does not } \\
\text { provide enough } \\
\text { information to assess } \\
\text { this criterion }\end{array}$ & $\begin{array}{l}\text { Makes little } \\
\text { contribution to the } \\
\text { body of knowledge }\end{array}$ & $\begin{array}{l}\text { Makes an important } \\
\text { contribution to the } \\
\text { body of knowledge }\end{array}$ & $\begin{array}{l}\text { Makes a highly } \\
\text { significant } \\
\text { contribution to the } \\
\text { body of knowledge }\end{array}$ \\
\hline
\end{tabular}

Based on 10 articles selected according to the inclusion area, we found 11 psychological antecedents that affect trust in $\mathrm{C} 2 \mathrm{C}$. These psychological antecedents are perceived of website quality (21.5\%), natural propensity to trust $(15.79 \%)$, other's trust of buyer/seller $(10.53 \%)$, trust among members in $\mathrm{C} 2 \mathrm{C}$ community $(10.53 \%)$, perceived security protection $(10.53 \%)$, virtual community quality $(5.26 \%)$, perceived risk $(5.26 \%)$, perceived privacy protection $(5.26 \%)$, cognitive trust $(5.26 \%)$, technology readiness $(5.26 \%)$, and fear of opportunism $(5.26 \%)$. We also found that age as a moderator influences trust in the perceived of website quality, and other's trust of buyer/seller.

\section{CONCLUSIONS}

This systematic literature review research discusses the psychological antecedents that affect consumer trust in C2C. Based on 10 articles that have obtained through 5 databases (ScienceDirect, ResearchGate, GoogleScholar, Garuda, and Psycnet), consumer trust in $\mathrm{C} 2 \mathrm{C}$ is influenced by several psychological antecedents, such as perceived of website quality, natural propensity to trust, trust among members in the $\mathrm{C} 2 \mathrm{C}$ community, other's trust of buyer/seller, virtual community quality, perceived risk, perceived security protection, perceived privacy protection, cognitive trust, technology readiness, and fear of opportunism are discussed in detail in the discussion. Although, there are still some other important things that need to be explored in further research. To fully understand the psychological antecedents that affect consumer trust in $\mathrm{C} 2 \mathrm{C}$ further research is needed, especially regarding the personalities of consumers in different groups (gender, ethnicity, social class, and age).

\section{DISCUSSIONS}

The purpose of this study is to find out what psychological antecedents that affect trust in $\mathrm{C} 2 \mathrm{C}$. After screening articles through 5 databases (ScienceDirect, ResearchGate, GoogleScholar, Garuda, and Psycnet) and getting a total of 1,118 articles, the authors finally got 10 articles that meet 
the inclusion criteria. Based on the results of these 10 journals, the authors found 11 factors that are psychological antecedents that affect consumer trust in C2C. Authors also found age as a moderator between perceived of website quality and other's trust of buyer/seller.

\subsection{Perceived of Website Quality}

A study conducted by Yoon and Ocenna [42] shows that the effect of perceived of website quality on consumer trust in $\mathrm{C} 2 \mathrm{C}$ is moderated by age. Yoon and Ocenna [42] mentioned that only users around 20 were affected by perceived of website quality. Users over 30 and 40 are not affected by this factor. This is because the younger generation is more familiar with the internet environment. A study by Jones and Leonard [43] states that when consumers do not know each other's sellers, consumers tend to focus on the website quality that is included in social signals. A study conducted by Chen et al. [44] also stated that perceived of website quality positively moderates the relationship between trust in the website and trust in sellers. However, in Leonard and Jones [45] study showed that there was no significant effect between perceived of website quality and consumer trust. 


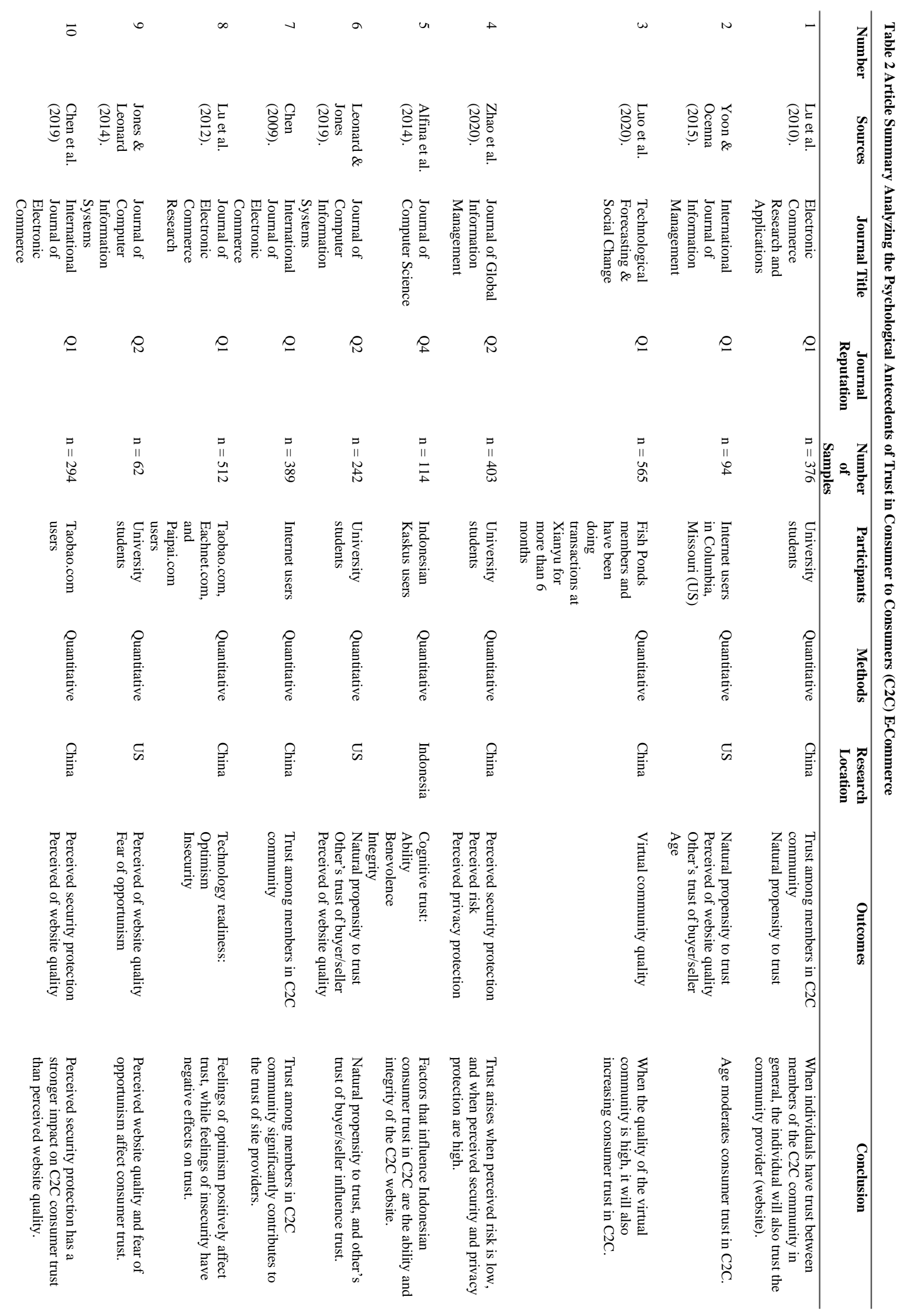


This study shows that perceived website quality has an influence on consumer trust because the website quality becomes the first impression which in turn makes consumers trust in the seller. So, in this case it is important for $\mathrm{C} 2 \mathrm{C}$ electronic sales service providers to always update the features on the website quality.

\subsection{Natural Propensity to Trust}

Leonard and Jones [45] study shows that natural propensity to trust influenced consumer trust in $\mathrm{C} 2 \mathrm{C}$. With the increasing use of $\mathrm{C} 2 \mathrm{C}$ as a consumer choice for transactions, Leonard and Jones [45] explain that this can allow consumers to rely on their natural trust behavior. A study conducted by $\mathrm{Lu}$ et al. [46] also showed a positive relationship between a natural propensity to trust and consumer trust in $\mathrm{C} 2 \mathrm{C}$. This also supports the theory about personality significantly influences individual attitudes towards other subjects [46]. Whereas a study conducted by Yoon and Ocenna [42], found that the natural propensity to trust did not significantly affect consumer trust in $\mathrm{C} 2 \mathrm{C}$. This study hypothesizes that the natural propensity to trust affect trust in $\mathrm{C} 2 \mathrm{C}$ because individual perceptions, intentions, attitudes, and motivations are influenced by personality [42]. However, the results are not following the hypothesis. This study concludes that the natural propensity to trust is one of the psychological antecedents that can influence consumer trust. It's because the natural propensity to trust is an attitude that is influenced by personality [46]. This study suggests further research about this antecedent by adding individual characteristics as a moderator.

\subsection{Other's Trust of Buyer / Seller}

The results of Yoon and Ocenna [42] study state that other's trust of buyer/seller only affects trust in $\mathrm{C} 2 \mathrm{C}$ for 40 years and above consumers. Consumers who are around 40 years old tend to have difficulty finding additional information via internet or other sources so they tend to depend on other's trust. Meanwhile, Leonard and Jones [45] found that other's trust of buyer/seller affects consumer trust in C2C. However, the results of this study show a negative relationship. The result didn't same as the initial expectations of researchers who hypothesized that there is a positive relationship between other's trust of buyer/seller and consumer trust in C2C. Leonard and Jones [45] mentioned the need for further research on this antecedent and focus more on who provides recommendations, such as friends, parents, siblings, strangers, athletes, celebrities, and others.

This study concludes that the influence of other's trust of buyer/seller has different effects, this can be moderated by age, individuals who provide recommendations, and level of the closeness of individuals who provide the information. Further research is needed regarding this factor by adding a moderator(s) that can influence this variable.

\subsection{Trust Among Members in The C2C Community}

Lu et al. [46] mentioned that there are causal antecedents that have a positive relationship to trust among members in the $\mathrm{C} 2 \mathrm{C}$ community, that it can ultimately affect consumer trust in $\mathrm{C} 2 \mathrm{C}$. The causative antecedents that have a positive relationship are familiarity and perception of similarities between members in the $\mathrm{C} 2 \mathrm{C}$ community. Lu et al. [46] stated that in an e-commerce environment when individuals tend to have many common characteristics between one member and another, it will help to build trust, even if they are not communicated directly. Chen et al. [44] also found a significant influence between trust among members in the $\mathrm{C} 2 \mathrm{C}$ community and consumer trust in C2C. If Lu et al. [46] stated that the antecedents that cause trust among $\mathrm{C} 2 \mathrm{C}$ members are familiarity and perception of similarity, in contrast to Chen et al. [44], which states that the antecedents that cause trust between $\mathrm{C} 2 \mathrm{C}$ members are the information and emotional interactions between $\mathrm{C} 2 \mathrm{C}$ members. Chen et al. [44] suggest that information and emotional interactions are the main contributing antecedents for mutual trust among members in the $\mathrm{C} 2 \mathrm{C}$ community. Overall, the existence of social interaction and relationships between members is very important for $\mathrm{C} 2 \mathrm{C}$ website providers.

\subsection{Virtual Community Quality}

Research by Luo et al. [50] mentioned that the high quality of virtual communities tends to affect consumer trust in $\mathrm{C} 2 \mathrm{C}$ more than perceived website quality. According to Luo et al. [50], this can happen because high virtual community interaction can place more emphasis on social activity among members and pay less attention to the quality of the website. Thus, C2C website providers should innovate interesting features that can improve the quality of the community, such as uploading product photos with reviews, discussions between community members about trends or phenomena, etc.

\subsection{Perceived Risk}

A study conducted by Zhao et al. [47] found that perceived risk has a negative relationship with consumer trust in $\mathrm{C} 2 \mathrm{C}$. When consumers have a low perceived risk, consumers tend to have high trust in $\mathrm{C} 2 \mathrm{C}$. Thus, $\mathrm{C} 2 \mathrm{C}$ website providers should provide features that can reduce consumer's perceived risk, such as guarantees from website service providers, the existence of applicable laws, and so on. This is in accordance with institutional factors that affect online consumer trust described by Chen [22].

\subsection{Perceived Security Protection}

A study from Zhao et al. [47] stated that perceived security protection is the strongest antecedent in consumer trust in $\mathrm{C} 2 \mathrm{C}$ compare to perceived risk and perceived privacy protection. Zhao et al. [47] mentioned that $\mathrm{C} 2 \mathrm{C}$ consumer trust in China is strongly influenced by how much the 
website provides strong security protection. This can happen because in the last 10 to 20 years, there were tend to be a lot of "wild" and fake e-commerce websites. A study conducted by Chen et al. [44] on users of C2C websites in China also states that perceived security protection tends to have a stronger influence on $\mathrm{C} 2 \mathrm{C}$ consumer trust than perceived of website quality. Although the perceived security protection factor appears only in 1 journal from China, this study argues that this factor can also affect almost all $\mathrm{C} 2 \mathrm{C}$ websites all around the world.

\subsection{Perceived Privacy Protection}

A study conducted by Zhao et al. [47] stated that perceived privacy protection has a positive relationship with consumer trust in $\mathrm{C} 2 \mathrm{C}$. With the high level of perceived privacy protection, consumer trust in $\mathrm{C} 2 \mathrm{C}$ will also be increasing. This study argues that if $\mathrm{C} 2 \mathrm{C}$ website providers can continue to improve consumer security protection, it can also improve the $\mathrm{C} 2 \mathrm{C}$ reputation, which can also increase consumer trust [22].

\subsection{Cognitive Trust}

A study conducted by Alfina et al. [48] on Indonesian C2C consumer, resulting in cognitive trust as an antecedent that positively and significantly influences consumer trust in C2C. In this study, Alfina et al. [48] state that there are several dimensions of cognitive trust, including ability, kindness, and integrity. However, in this study, only ability and integrity have a positive influence on consumer trust in $\mathrm{C} 2 \mathrm{C}$. Even though the study is from Indonesia, this study suggests that all sellers on the $\mathrm{C} 2 \mathrm{C}$ all around the world can increase their knowledge about the products they sell, and be more honest with buyers about the condition and quality of products to increase consumer trust.

\subsection{Technology Readiness}

A study by $\mathrm{Lu}$ et al. [49] revealed the influence of technology readiness on consumer trust in $\mathrm{C} 2 \mathrm{C}$. $\mathrm{Lu}$ et al. [49] explain that there are several dimensions of technology readiness, namely optimism, innovation, insecurity, and discomfort. Lu et al. [49] found that the optimism dimension was the antecedent that had the most positive influence on consumer trust in $\mathrm{C} 2 \mathrm{C}$. Thus, $\mathrm{C} 2 \mathrm{C}$ consumers who have a sense of optimism for technology tend to perceive that $\mathrm{C} 2 \mathrm{C}$ websites are trustworthy. Meanwhile, innovation does not have a significant effect on consumer trust in $\mathrm{C} 2 \mathrm{C}$. The dimension of feeling insecure has a negative influence on consumer trust in $\mathrm{C} 2 \mathrm{C}$. These findings illustrate that when $\mathrm{C} 2 \mathrm{C}$ consumers feel insecure in the technology environment in general, the less likely to trust the $\mathrm{C} 2 \mathrm{C}$ websites.

\subsection{Fear of Opportunism}

A study conducted by Jones and Leonard [43] shows that fear of opportunism is one of the antecedents that affect consumer trust in $\mathrm{C} 2 \mathrm{C}$. Jones and Leonard [43] provide advice to sellers on the $\mathrm{C} 2 \mathrm{C}$ website to find out how to display good product photos so that consumers can ensure that the quality contained in the photos matches with the product description. Jones and Leonard [43] also mentioned that sellers must provide comprehensive information about any problems with the product before the transaction occurs to reduce buyer fear. Further research is needed on this antecedent, mainly by adding a moderator of other individual characteristics such as age, culture, social class, etc. Thus, future research can get more focused results regarding the characteristics of individuals who tend to have a fear of the online sales environment. So, the practical advice presented will be more in line with target consumers.

\section{SUGGESTIONS}

\subsection{Suggestions for Future Studies}

Research on the psychological antecedents that influence consumer trust in $\mathrm{C} 2 \mathrm{C}$ is still limited. Further research is needed to explore the psychological aspects that affect consumer trust in $\mathrm{C} 2 \mathrm{C}$. Authors suggest investigating more on personal characteristics, and personality factors because as mentioned by Ryckman (cited in Yoon \& Ocenna) [42], that personality can influence individual perceptions, intentions, attitudes, motivations, and behaviors. Meanwhile, research on consumer personality and trust in $\mathrm{C} 2 \mathrm{C}$ is still very limited. There is limited research examining the impact of moderators on the relationship between psychological antecedents and consumer trust in $\mathrm{C} 2 \mathrm{C}$. Thus, more research is needed on the role of moderation in this research topic. Further research is suggested to add data collection techniques, such as snowball sampling or other sources.

\subsection{Suggestions for Practical}

Based on the results of this study, the perceived of website quality is an important antecedent of consumer trust in C2C [42]. Therefore, C2C website providers should often survey $\mathrm{C} 2 \mathrm{C}$ consumers to find out their experience in accessing the websites. So that $\mathrm{C} 2 \mathrm{C}$ website providers can develop the quality of the website periodically to increase consumer's perceived of website quality and trust. The presence of a virtual community of $\mathrm{C} 2 \mathrm{C}$ shows a significant and positive relationship to consumer trust in $\mathrm{C} 2 \mathrm{C}$. $\mathrm{C} 2 \mathrm{C}$ website providers may consider adding virtual communities on their websites, because, in addition to increase the consumer trust, the presence of this virtual community can also increase purchase intention [50].

\section{REFERENCES}

[1] Antaranews.com. (2020, 17 April). Criteo: Penjualan online meningkat di tengah pandemi COVID-19. Diakses pada 10 September 2020, diunduh dari https://www.antaranews.com/berita/1427837/criteo- 
penjualan-online-meningkat-di-tengah-pandemi-covid19

[2] Statista. (2020). Thinking about your everyday life, since the COVID-19 / coronavirus pandemic, have you made any changes to your general lifestyle? Diunduh dari https://www.statista.com/statistics/1105960/ changes-to-the-general-lifestyle-due-to-covid-19-inselected-countries/

[3] Badan Pusat Statistik (BPS). (2020). Tinjauan Big Data Terhadap Dampak Covid-19 2020.

[4] VOA. (2018, 19 Desember). E-commerce Growing Among Internet Savvy Indonesians. Diakses pada 7 Oktober 2020, diunduh dari https://www.voanews.com/ east-asia-pacific/e-commerce-growing-among-internetsavvy-indonesians

[5] Wang, K., Wang, E. T. G., \& Tai, C. F. (2002). A study of online auction sites in Taiwan: Product, auction rule, and trading type. International Journal of Information Management, 22(2), 127-142. https://doi. org/10.1016/S0268-4012(01)00050-0

[6] Pono, V. G. L. R., Handayani, P. W., Sandhyaduhita, P. I., \& Azzahro, F. (2019). Trust in Merchants and Ecommerce Platforms as Antecedents of Users' Purchase Intention in $\mathrm{C} 2 \mathrm{C}$ E-Commerce. 5th International Conference on Computing Engineering and Design, ICCED 2019, 2-7. https://doi.org/10.1109/ICCED 46541.2019 .9161137

[7] Yanchun, Z., Wei, Z., \& Changhai, Y. (2011). Detection of feedback reputation fraud in Taobao using social network theory. Proceedings - 2011 International Joint Conference on Service Sciences, IJCSS 2011, 188192. https://doi.org/10.1109/IJCSS.2011.44

[8] Xianqiang, M., Bingjia, S., \& Junhui, H. (2009). Empirical study on factors influencing $\mathrm{C} 2 \mathrm{C}$ online fraud in china. 2009 8th International Conference on Mobile Business, 273-277. https://doi.org/10.1109/ICMB.2009. 53

[9] Beldad, A., De Jong, M., \& Steehouder, M. (2010). How shall i trust the faceless and the intangible? A literature review on the antecedents of online trust. Computers in Human Behavior, 26(5), 857-869. https:// doi.org/10.1016/j.chb.2010.03.013

[10] Gefen, D., Karahanna, E., \& Straub, D. W. (2003). Trust and TAM in Online Shopping: An Integrated Model. MIS Quarterly, 27(1), 51-90. https://doi.org/10. 1017/CBO9781107415324.004
[11] Ha, S., \& Stoel, L. (2009). Consumer e-shopping acceptance: Antecedents in a technology acceptance model. Journal of Business Research, 62(5), 565-571. https://doi.org/10.1016/j.jbusres.2008.06.016

[12] Pavlou, P. A. (2003). Consumer acceptance of electronic commerce: Integrating trust and risk with the technology acceptance model. International Journal of Electronic Commerce, 7(3), 101-134. https://doi.org/10. $1080 / 10864415.2003 .11044275$

[13] Angriawan, A., \& Thakur, R. (2008). A parsimonious model of the antecedents and consequence of online trust: An uncertainty perspective. Journal of Internet Commerce, 7(1), 74-94. https://doi.org/10. $1080 / 15332860802004337$

[14] Leonard, L. N. K., \& Jones, K. (2019). Trust in C2C Electronic Commerce: Ten Years Later. Journal of Computer Information Systems, 0(0), 1-7. https://doi. org/10.1080/08874417.2019.1598829

[15] Fang, Y., Qureshi, I., Sun, H., Mccole, P., Ramsey, E., Lim, K. H., \& Echanisms, M. (2014). Trust, Satisfaction, and Online Repurchase Intention: The Moderating Role of Perceived Effectiveness of Ecommerce Institutional. 38(2), 407-428.

[16] Kotler P., \& Armstrong, G. (2012). Principles of Marketing.

[17] Mou, J., Shin, D. H., \& Cohen, J. (2016). Understanding trust and perceived usefulness in the consumer acceptance of an e-service: a longitudinal investigation. Behaviour and Information Technology, 36(2), 125-139. https://doi.org/10.1080/0144929X. 2016.1203024

[18] Punyatoya, P. (2019). Effects of cognitive and affective trust on online customer behavior. Marketing Intelligence and Planning, 37(1), 80-96. https://doi.org/ 10.1108/MIP-02-2018-0058

[19] Bart, Y., Shankar, V., Sultan, F., \& Urban, G. L. (2005). Determinants and Role of Trust in E-Business: A Large-Scale Empirical Study. SSRN Electronic Journal, 69(October), 133-152. https://doi.org/10.2139/ssrn. 380404

[20] Lewis, J. D., \& Weigert, A. (1985). Trust as a Social Reality. Social Forces, 4(1), 967-985.

[21] Morrow, J. L., Hansen, M. H. M., \& Pearson, A. W. A. (2004). The cognitive and affective antecedents of general trust within cooperative organizations. Journal of Managerial Issues, 16(1), 48-64. http://www.jstor.org/ discover/10.2307/40601183?sid=21105283239111\&uid 
$=62 \&$ uid $=3739256 \&$ uid $=3 \&$ uid $=22333 \&$ uid $=67 \&$ uid $=$ 2\&uid=19491176\&uid=3739840\&uid=19491808

[22] Chen, C. (2006). Identifying Significant Factors Influencing Consumer Trust in an Online Travel Site. Information Technology \& Tourism, 8, 197-214. https:// doi.org/10.3727/109830506778690849

[23] Chen, J., \& Dibb, S. (2010). Understanding the Acceptance of Mobile SMS Advertising among Young Chinese Consumers. Psychology \& Marketing, 27(4), 323-346. https://doi.org/10.1002/mar

[24] Shapiro, S. P. (1987). The Social Control of Impersonal Trust. American Journal of Sociology, 93(3), 623-658. https://doi.org/10.1086/228791

[25] Koufaris, M., \& Hampton-sosa, W. (2002). Customer Trust Online: Examinin the Role of the Web Site. Cis, 5, 1-20.

[26] Hoffman, D. L., Novak, T. P., \& Peralta, M. (1999). Building Consumer Trust Online. Communications of the ACM, 42(4), 80-85. https://doi.org/10.1145/299157. 299175

[27] Lynch, P. D., Kent, R. J., \& Srinivasan, S. S. (2001). The global internet shopper: Evidence from shopping tasks in twelve countries. Journal of Advertising Research, 41(3), 15-23. https://doi.org/10.2501/JAR41-3-15-23

[28] Pavlou, P. A., \& Fygenson, M. (2006). Understanding and Predicting Electronic Commerce Adoption: An Extension of the Theory of Planned Behavior. MIS Quarterly, 30(1), 115-143. DOI: $10.2307 / 25148720$

[29] McKnight, D. H., Choudhury, V., \& Kacmar, C. (2002). The impact of initial consumer trust on intentions to transact with a web site: A trust building model. Journal of Strategic Information Systems, 11(3-4), 297323. https:// doi.org/10.1016/S0963-8687(02)00020-3

[30] Heijden, H. Van Der., Verhagen, T., \& Creemers, M. (2003). Understanding online purchase intentions: Contributions from technology and trust perspectives. European Journal of Information Systems, 12(1), 41-48. https://doi.org/10.1057/palgrave.ejis.3000445

[31] Kim, D. J., Ferrin, D. L., \& Raghav Rao, H. (2009). Trust and satisfaction, two stepping stones for successful e-commerce relationships: A longitudinal exploration. Information Systems Research, 20(2), 237-257. https:// doi.org/10.1287/isre.1080.0188
[32] Mahliza, F. (2020). Consumer Trust in Online Purchase Decision. EPRA International Journal of Multidisciplinary Research (IJMR), 6(2).

[33] Kaplan, S. E., \& Nieschwietz, R. J. (2003). An Examination of the Effects of WebTrust and Company Type on Consumers' Purchase Intentions. International Journal of Auditing, 7(2), 155-168. https://doi.org/10. $1111 / 1099-1123.00066$

[34] Wu, I. L. (2013). The antecedents of customer satisfaction and its link to complaint intentions in online shopping: An integration of justice, technology, and trust. International Journal of Information Management, 33(1), 166-176. https://doi.org/10.1016/j.ijinfomgt. 2012.09.001

[35] Chiu, C. M., Hsu, M. H., Lai, H., \& Chang, C. M. (2012). Re-examining the influence of trust on online repeat purchase intention: The moderating role of habit and its antecedents. Decision Support Systems, 53(4), 835-845. https://doi.org/10.1016/j.dss.2012.05.021

[36] Flavián, C., Guinalíu, M., \& Gurrea, R. (2006). The role played by perceived usability, satisfaction and consumer trust on website loyalty. Information and Management, 43(1), 1-14. https://doi.org/10.1016/j.im. 2005.01.002

[37] Qureshi, I., Fang, Y., Ramsey, E., McCole, P., Ibbotson, P., \& Compeau, D. (2009). Understanding online customer repurchasing intention and the mediating role of trust- An empirical investigation in two developed countries. European Journal of Information Systems, 18(3), 205-222. https://doi.org/10.1057/ejis. 2009.15

[38] Mittal, A. (2013). E-commerce It's Impact on Consumer Behavior. 3(2), 131-138.

[39] Nguyen, D. H., Leeuw, S., \& Dullaert, W. E. H. (2018). Consumer behavior and order fulfilment in online retailing: A systematic review. International Journal of Management Reviews, 20, 255-276. https://doi.org/10.1111/ijmr.12129

[40] Macpherson, A., \& Holt, R. (2007). Knowledge, learning and small firm growth: A systematic review of the evidence. Research Policy, 36(2), 172-192. https://doi.org/ 10.1016/j.respol.2006.10.001

[41] Wong, C., Skipworth, H., \& Godsell, J. (2012). Towards a theory of supply chain alignment enablres: a systematic literature review. Supply Chain Management: An International Journal, 17(4), 419-437. https://doi. org/ $10.1108 / 13598541211246567$ 
[42] Yoon, H. S., \& Occeña, L. G. (2015). Influencing factors of trust in consumer-to-consumer electronic commerce with gender and age. International Journal of Information Management, 35(3), 352-363. https://doi. org/10.1016/j.ijinfomgt.2015.02.003

[43] Jones, K., \& Leonard, L. N. L. (2014). Factors influencing buyer's trust in consumer-to-consumer ecommerce. Journal of Computer Information Systems, 54(4), 71-79. http://dx.doi.org/10.1080/08874417.2014. 11645724

[44] Chen, X., Huang, Q., Davison, R. M., \& Hua, Z. (2015). What drives trust transfer? The moderating roles of seller-specific and general institutional mechanism. International Journal of Electronic Commerce, 20(2), 261-289. http://dx.doi.org/10.1080/10864415.2016. 1087828

[45] Leonard, L. N. K., \& Jones, K. (2019). Trust in C2C Electronic Commerce: Ten Years Later. Journal of Computer Information Systems, 0(0), 1-7. https://doi.org/ 10.1080/08874417.2019.1598829

[46] Lu, Y., Zhao, L., \& Wang, B. (2010). From virtual community members to $\mathrm{C} 2 \mathrm{C}$ e-commerce buyers: trust in virtual communities and its effect on consumers' purchase intention. Electronic Commerce Research and Applications, 9, 346-360. https://doi.org/10.1016/j. elerap.2009.07.003

[47] Zhao, S., Fang, Y., Zhang, W., \& Jiang, H. (2020). Trust, perceived benefit, and purchase intention in c2c ecommerce: an empirical examination in china. Journal of Global Information Management, 28(1), 121-141. https://doi.org/10.4018/JGIM.2020010107

[48] Alfina, I., Ero, J., Hidayanto, A. N., \& Shihab, M. R. (2014). The impact of cognitive trust and e-wom on purchase intention in c2c e-commerce site. Journal of Computer Science, 10(2), 2518-2514. https://doi.org10. 3844/jcssp.2014.2518.2524

[49] Lu, J., Wang, L., Hayes, L. A. (2012). How do technology readiness, platform functionality and trust influence c2c user satisfaction? Journal of Electronic Commerce Research, 13(1), 50-69.

[50] Luo, N., Wang, Y., Zhang, M., Niu, T., \& Tu, J. (2020). Integrating community and e-commerce to build a trusted online second-hand platform: based on the perspective of social capital. Technological Forecasting \& Social Change, 153. https://doi.org/10.1016/j. techfore.2020.119913 